\title{
PENOKOHAN DALAM NOVEL SURAT KECIL UNTUK TUHAN KARYA AGNES DAVONAR (KAJIAN STRUKTURAL)
}

\author{
Peni Berta Renmaur \\ Merlyn Rutumalessy \\ Universitas Pattimura \\ e-mail: PeniRenmaur@yahoo.com
}

\begin{abstract}
Abstrak: Novel merupakan karya sastra berbentuk prosa dan juga berhubungan dengan kehidupan seseorang yang dibuat dalam bentuk cerita. Tujuan dari penelitian ini, yaitu mendeskripsikan penokohan dalam novel Surat Kecil untuk Tuhan karya Agnes Davonar. penokohan merupakan pelukisan gambaran yang jelas mengenai seseorang yang ditampilkan dalam cerita. Dari penelitian ini ditemukan dua tokoh utama, yaitu tokoh Anton dan Angel, dan beberapa tokoh pendukung lainnya seperti paman Marcus, bibi Feli, tante Soraya dan suaminya, om Rudy, Maria, Martin Wira dan Mirna.
\end{abstract}

Kata Kunci: Penokohan 


\title{
CHARACTERIZATION IN A SMALL LETTER NOVEL TO GOD BY AGNES DAVANOR (STRUCTURAL STUDY)
}

\author{
Peni Berta Renmaur \\ Merlyn Rutumalessy \\ Universitas Pattimura \\ e-mail:PeniRenmaur@yahoo.com
}

\begin{abstract}
The novel is a literary work in the form of prose and Also relates to the live of someone made in the form of stories. The purpose of this research is to describe the characterizations in my little letter novel to god by Agnes Davonar. Characterization is the painting of a clear picture of someone who is featured in the story. From this study found two main figures namely the figures Anton and Angel, and several other supporting figures such as uncle Markus, Aunt Feli, Auntie Soraya and her Husband, Uncle Rudy, Maria, Martin Wira and Mirna.
\end{abstract}

Keywords: Characterizations 


\section{A. PENDAhuluan}

Karya sastra adalah bentuk komunikasi yang diucapkan dengan cara yang khas dan memberikan kemampuan kepada pengarang untuk menuangkan kreativitas imajinasinya seperti ungkapan pikiran dan perasaan, berupa kisah maupun kehidupan sehari-hari. Hal ini yang menjadikan karya sastra menjadi sempurna sehingga memiliki berbagai kemungkinan dalam memahami karya sastra tersebut dari inilah kemudia timbul berbagai teori yang mengkaji karya sastra, termasuk karya sastra novel.

Novel merupakan salah satu bentuk karya sastra. Novel merupakan karya sastra berbentuk prosa dan juga berhubungan dengan kehidupan seseorang yang dibuat dalam bentuk cerita. Novel juga bercerita mengenai kehidupan manusia dalam berinteraksi satu dengan yang lain dalam lingkungan sosial. Dalam sebuah novel, penulis berupaya untuk mengarahkan pembaca kepada gambaran-gambaran tentang kenyataan sesungguhnya tentang cerita yang terdapat dalam novel tersebut.

Unsur intrinsik merupakan unsur novel yang dapat dilihat pada saat buku atau novel tersebut dibaca, selain itu unsur-unsur intrinsik novel juga merupakan bagian penting yang harus ada sebagai pelengkap dari sebuah novel dalam membangun isi dari cerita novel tersebut seperti, tema, tokoh, latar, alur, amanat, sudut pandang, dan gaya bahasa. Unsur tersebut merupakan srtuktur yang dapat dibuat sebagai pelengkap cerita.

Panuti-Sudjiman (dalam Sugihastuti dan suharto, 2002; 50) menjelaskan tentang cerita rekaan pada dasarnya menceritakan tentang beberapa orang yang menjadi tokoh dalam cerita. Tokoh cerita adalah seseorang yang berperan serta mengalami peristiwa atau perlakuan dalam berbagai peristiwa. Tokoh cerita merupakan subjek yang memerankan peristiwa-peristiwa cerita yang disertai dengan tingkah laku serta watak dari karakter tertentu. Watak merupakan karakter tokoh yang berhubungan dengan nalar dan jiwa serta membedakannya dengan yang lain. Tokoh dalam cerita sangat penting untuk menjelaskan bagian cerita yang ada, disesuaikan dengan watak yang dibuat oleh pengarang.

Watak atau karakter yang diperankan oleh tokoh tersebut hanyalah rekaan yang dibuat oleh penulis, watak tersebut biasanya sama dengan watak seseorang dalam kehidupan nyata. Kesamaan watak dapat merangsang pembaca agar lebih mudah dalam memahami serta mengerti alur sebuah cerita yang dibuat oleh penulis. Watak tersebut mengarah pada tokoh agar dapat menampilkan karakter sesuai dengan peran yang didapat sehingga membuat cerita menjadi lebih menarik. Baldie (dalam Nurgiantoro 2002 : 247) menyatakan bahwa tokoh merupakan bagian dari karakter seorang yang berperan menjadi pelaku dalam cerita fiksi atau drama. Penokohan (characterization) adalah kehadiran tokoh dalam cerita fiksi atau drama yang secara langsung dan tidak langsung dan merangsang pembaca untuk menafsirkan kemampuan dirinya melalui kata atau tindakannya. Salah satu contoh dalam penamaan tokoh dalam sebuah cerita seperti dalam tokoh yang diberi nama Anton dan Angel dalam novel Surat Kecil Untuk Tuhan. Nama berfungsi untuk mempermudah penyebutan tokoh dalam cerita, serta menjelaskan kualitas dan latar belakang pemiliknya. 
Pada penelitian ini, peneliti menggunakan novel Surat Kecil untuk Tuhan karya Agnes Davonar yang diterbitkan pada tahun 2016 sebagai bahan penelitian. Novel Surat Kecil untuk Tuhan karya Agnes Davonar dipilih dalam penelitian ini karena sangat menarik untuk dikaji karena novel Surat Kecil untuk Tuhan karya Agnes Davonar ini mengisahkan kisah nyata yang sangat mengharukan sehingga mengundang air mata para pembaca. Terlebih cara penulis menyampaikan kisah dua anak kecil yang bernama Anton dan Angel yang ditinggal oleh kedua orang tuanya, sehingga Anton dan Angel harus memperjuangkan hidup mereka tanpa orang tua mereka.

Ada beberapa alasan lain peneliti tertarik terhadap novel Surat Kecil untuk Tuhan karya Agnes Davonar yaitu sebagai berikut;

Tokoh pemeran pada novel Surat Kecil untuk Tuhan ini adalah tokoh anak yang penuh perjuangan dan sabar dalam menghadapi setiap cobaan dalam hidup mereka. Pengalaman hidup yang kelam yang kebanyakan terjadi dimasa kini dapat dilalui oleh tokoh utama melalui watak serta peran yang patut dijadikan contoh dan teladan bagi kita. Peristiwa -peristiwa dalam novel tersebut memberikan makna kehidupan yang dalam, bahwasanya kita senantiasa bersyukur terhadap karunia Tuhan. Kita dapat mengimplikasikan nilai-nilai kehidupan yang positif dari kisah kehidupan yang dilalui oleh pemeran utama yang disertai dengan karakter tokoh ke dalam kehidupan seharihari kita.

Nilai-nilai kehidupan yang dapat dipetik dari novel ini, seperti halnya nilai moral yang dilakukan oleh orang tua asuh Angel yang berhati tulus dan iklas menggambarkan realita kehidupan bahwasanya memang sebagian orang tidak memandang dari kondisi sosial kehidupan seseorang. Kerukunan Anton dan Angel sebagai seorang kakak beradik dan sikap yang sangat mandiri dalam novel ini membawa pembaca berandaiandai jika semua anak yang hidup bersama orang tuanya juga bersikap seperti Anton dan Angel. Selain itu nilai yang berasal dari tindakan Angel ketika ia ingin memperjuangkan hak-hak anak-anak jalanan. Pada dasarnya semua karya sastra yang dibuat pasti mengandung nilai kehidupan yang dapat dicontoh oleh pembaca seperti halnya novel Surat Kecil untuk Tuhan karya Agnes Davonar ini.

Agnes Davonar adalah nama penulis yang terdiri atas gabungan nama dari dua kakak-beradik yang sukses dalam menggapai puncak keemasan melalui dunia sastra yang sudah mereka ciptakan. Berbagai macam karyanya sudah sangat terkenal dan menjadi fenomenal, bahkan juga menjadi best-seller sebagai bukti dari popularitasnya dalam dunia sastra.

Novel Surat Kecil untuk Tuhan termasuk dalam jenis novel inspirasi karena, novel ini bisa menginspirasi pembaca untuk memperoleh nilai moral serta manfaat yang dapat diambil dalam novel ini ialah agar orang tua lebih waspada dalam menjaga anak. Tema yang disuguhkan dalam jenis novel inspirasi ini bermacam-macam contoh tema ekonomi, tema pendidikan, tema kehidupan dan perjuangan. Berdasarkan kejadian nyata dan tidaknya, novel ini termasuk dalam jenis novel non fiksi. Novel non fiksi adalah cerita yang pernah terjadi atau nyata serta pernah ada dan dialami. 
Berdasarkan uraian di atas, maka penulis ingin mengkaji lebih dalam penokohan dalam novel Surat Kecil untuk Tuhan karya Agnes Davonar yang dikaji dengan Kajian Struktural. Gambaran penokohan dalam novel ini diawali dengan analisis struktur yang meliputi tema, alur, tokoh, dan latar. Analisis penokohan dalam novel Surat Kecil untuk Tuhan karya Agnes Davonar menggunakan pendekatan struktural.

\section{B. PEMBAHASAN}

Kata novel dalam bahasa Latin disebut novellus yang diambil dari kata novies yang berarti -baru', (Tarigan, 2011:167). Dikatakan baru karena bila dibandingkan dengan jenis sastra seperti puisi, drama, dan lainnya maka novel ini muncul kemudian. Jassin dalam (Nurgiantoro 1994:18) novel adalah suatu cerita yang berperan dalam kehidupan manusia serta benda yang ada di sekitar kita yang lebih banyak menceritakan tentang kehidupan seseorang.Nurgiantoro (2002 : 5) mengemukakan bahwa novel sebagai karya berupa fiksi mengambarkan sebuah dunia, yang berisi tentang model kehidupan yang dirancang oleh imajinatif, yang dibentuk dengan berbagai unsur intrinsiknya seperti, peristiwa, plot, tokoh, penokohan, latar, sudut pandang, dan lainlain yang kesemuanya juga bersifat imajinatif. Menurut KBBI novel merupakan karangan prosa yang panjang berupa bagian cerita kehidupan seseorang dengan orang ada disekelilingnya yang menunjukan sifat setiap tokoh.

Kajian struktural merupakan pengkajian terhadap karya sastra, berupa prosa fiksi, yang menganggap obyek pengamatannya tidak hanya sekumpulan unsur yang terpisah, melainkan sebagai suatu gabungan terhadap unsur yang saling berhubungan erat atau koherensi. Struktur merupakan bagian yang memperlihatkan hubungan antara unsur pembentuk karya sastra dengan rangkaian unsur yang tersusun secara teratur (Zaidan, dkk, 2004 : 194).

Yang termaksud dalam Prosa fiksi, ialah tema, plot, penokohan, latar, sudut pandang, dan bahasa. Pada hakekatnya kajian struktural bertujuan memaparkan secermat mungkin fungsi dan keterkaitan antar berbagai unsur karya sastra, dalam hal ini prosa fiksi yang secara bersama menghasilkan sebuah kemenyeluruhan. Kajian struktur tidak cukup kalau hanya sekedar mendata unsur tertentu pada sebuah karya prosa fiksi, misalnya peristiwa, alur, tokoh, latar, atau yang lainnya. Namun yang terpenting adalah menjelaskan bagaimana hubungan antar unsur itu, atau bagian apa saja yang diberikan terhadap tujuan estetika serta makna yang ingin dicapai (Nurgiyantoro, 2002:37).

Abrams (dalam Nurgiyantoro, 2002 : 36) menjelaskan bahwa -struktur karya sastra dapat diartikan sebagai susunan, penegasan dan gambaran semua bahan dan bagian yang menjadi komponennya yang secara bersama membentuk kebulatan yang indahll. Analisis struktural adalah bagian dari kajian kesusastraan yang berhubungan antar unsur pembangun karya sastra. Struktur pembentuk karya sastra tersebut ialah: penokohan, alur, pusat pengisahan, latar, tema, dan sebagainya. Struktur novel atau 
cerpen yang ada dihadapan pembaca yaitu bagian dari sebuah totalitas. Novel atau cerpen dibangun dari sejumlah unsur yang akan saling berhubungan, saling menentukan, sehingga novel atau cerpen tersebut dapat berupa sebuah karya yang bermakna dalam hidup. Struktur diteliti meliputi: tema, pemplotan, penokohan, pelataran, sudut pandangan dan gaya bahasa. Dalam struktur karya sastra terdapat makna yang terpadu dan bulat, dengan syarat yaitu : Pertama pertama, ide kesatuan sebuah struktur hanya menjelaskan satu kesatuan yang bulat dan utuh. Bagian atau unsur membentuk struktur tidak dapat berdiri sendiri. Unsur yang satu dengan lainnya harus saling kait-mengait. Kedua, sebuah struktur itu harus terdapat gagasan transformasi dengan arti struktur itu tidak statis namun dinamis. Sebuah struktur mampu melakukan prosedur-prosedur yang baru dan dapat diperolah melalui prosedur tersebut. Ketiga, sebuah struktur mengatur dirinya sendiri. Artinya struktur tersebut tidak membutuhkan bantuan dari luar dirinya untuk mengisahkan prosedur transformasinya (Suroso, dkk 2009:81).

Unsur intrinsik (intrinsic) adalah unsur yang membentuk karya sastra itu sendiri. Unsur inilah yang menyebabkan sebuah teks muncul sebagai sebuah teks sastra. Unsurunsur yang secara nyata akan dijumpai ketika pembaca membaca sebuah karya sastra. Unsur intrinsik sebuah novel adalah unsur yang secara langsung turut serta dalam membangun sebuah cerita. kepanduan antar unsur intrinsik inilah yang akhirnya membuat sebuah novel berwujud atau jika dilihat dari sudut pandang pembaca, unsur inilah yang akan ditemukan ketika pembaca membaca sebuah novel. Unsur yang dimaksud seperti, peristiwa, cerita, plot, tokoh dan lain-lain (Nurgiantoro, 1994 : 30)

Dalam sebuah cerita fiksi, selalu digunakan sebuah istilah seperti tokoh dan penokohan, watak dan perwatakan, atau karakter dan karakterisasi secara bergantian dengan menujukan maksud yang hampir mirip. Istilah tersebut, sebenarnya tidak sama dengan pengertian yang sama persis atau setidaknya dalam penulisan ini akan dipergunakan dalam pengertian yang berbeda walau ada di antaranya yang bersinonim yang menunjuk pada tokoh cerita dan pada teknik perkembangannya dalam sebuah cerita.

Istilah tokoh merujuk pada orangnya, pelaku cerita, misalnya sebagai jawaban terhadap pertanyaan: -Siapakah tokoh utama novel itu?' Watak, perwatakan, dan karakter, menunjuk pada sifat dan sikap para tokoh seperti yang ditafsirkan oleh pembaca, lebih menunjuk pada kualitas pribadi seorang tokoh. Sudjiman (dalam Sugihastuti dan Suharto 2002: 86) tokoh adalah individu rekaan yang mengalami peristiwa atau berlakuan dalam berbagai peristiwa dalam cerita. Penokohan dan karakteristik juga disamakan artikan dengan karakter dan perwatakan menunjuk pada penempatan tokoh-tokoh tertentu dengan watak-watak tertentu.

Jones (dalam Nurgiyantoro 2002 : 247) menjelaskan bahwa penokohan merupakan pelukisan gambaran yang jelas mengenai seseorang yang ditampilkan 
dalam cerita. Tokoh dan penokohan memiliki keterkaitan dalam sebuah cerita yakni keberadaan tokoh atau jenis tokoh dapat menentukan penokohan atau perwatakan pada masing-masing tokoh pada sebuah cerita tersebut.

\section{Tokoh-tokoh yang berperan dalam novel Surat Kecil untuk Tuhan yaitu :}

\section{a. Angel}

Angel adalah pemeran utama dalam novel Surat Kecil untuk Tuhan (SKUT) karena tokoh Angel paling dominan keluar di dalam cerita. Tokoh ini juga paling sering dimunculkan dalam cerita dan juga menentukan alur cerita. Angel merupakan adik dari Anton. Angel merupakan sosok yang sangat cerdas, rajin, tegar, semangat, baik hati, penyayang dan pemberani.

Dalam novel SKUT halaman : 2 -Disampingnya, seorang gadis kecil berambut lurus sebahu duduk di kasur dengan wajah penuh kebingungan. Angel, si gadis cilik berusia 6 tahun itu, terus memegangi perutn ya yang laparll.

Dalam novel SKUT halaman : 125 -Lima tahun berlalu.. Angel dan keluarganya sudah pindah ke Sydney karena Edwards mendapatkan tugas baru di bagian imigrasi, di kota yang terkenal dengan gedung opera unik ini. Angel telah tumbuh menjadi gadis yang cerdas dan enerjik berusia 12 tahunll.

Dalam novel SKUT halaman : 158 -Ketulusan dan pertolongan Angel untuk ibu yang tak berdaya itu membuat namanya menjadi tenar. Kasus ini memang dari awal telah menarik perhatian media lokal yang selalu memberitakan perkembangannya. Setelah menengani kasus ini, nama Angel mulai diperhitungkan sebagai pengacara muda tempat masyarakat kecil bisa mengadu dan meminta pertolongan secara hukumll.

\section{b. Anton}

Anton merupakan pemeran utama dalam novel Surat Kecil untuk Tuhan karena tokoh Anton sering muncul dalam cerita. Anton adalah kakak kandung dari Angel yang selalu menjaga adiknya mulai dari kehujanan, kepanasan, bahkan Anton rela mau mengikuti semua perintah om Rudy untuk kesembuhan adiknya. Anton polos dan sangat jujur.

Dalam novel SKUT halaman : 2 -Angel si gadis cilik berusia 6 tahun itu, terus memegangi perutnya yang lapar. Matanya yang bulat dan jernih mengikuti gerakan Anton, sang kakak yang masih sibuk mencari benda lain untuk menampung air bocoran dari atap genteng rumah merekall.

Dalam novel SKUT halaman : 7 -Anton menaburkan bunga di atas tanah kuburan ayah dan ibu dengan penuh air mata. Angel tidak mengerti apa yang terjadi, ia hanya mengikuti apa yang diperintahkan sang bibi. Doa dan salam perpisahan 
diucapkan dalam hati sang kakak untuk kedua orangtuanya. Ia berjanji akan menjaga adiknya dengan segenap jiwa dan raga di depan makam ayah dan ibu merekall.

Dalam novel SKUT halaman : 9 -Biasanya, setelah membantu mengangkat barang bawaan belanja pelanggan, Anton akan mendapatkan uang receh yang ia kumpulkan diam-diam dari bibinya. Uang itu kemudian sebagian ia belikan coklat atau jajanan untuk diberikan pada Angel saat pulang. Bila Anton pulang dengan coklat dan manisan, Angel akan begitu gembira dan suka cita menyambut setelah sekian lama menunggu di rumahll.

Dalam novel SKUT halaman : 54 -Anton kemudian mendekati adiknya. Ia tidak menyuruh Angel untuk mengamen, dan membiarkan adiknya berdiam diri di kolong jalan layang\|l.

\section{c. Om Rudy}

Om Rudy merupakan tokoh antagonis dalam novel Surat Kecil untuk Tuhan, karena tokoh ini sangat penting dalam perkembangan alur dan penyebab munculnya konflik. Om Rudy merupakan orang tua asuh dari Anton dan Angel. Om Rudy adalah tokoh yang sangat kejam dan jahat. Sosok Om Rudy digambarkan pada novel tersebut ialah sosok yang sangat tidak bermoral dan tidak berprikemanusiaan. Dia tega mengorbankan anak-anak yatim piatu dengan mengeksploitasi dan menjual organ tubuh mereka ke pasar gelap hanya semata-mata demi uang dan kebutuhannya.

Dalam novel SKUT halaman : 45 -Keesokan harinya. Setelah makan pagi, Om Rudy membawa Angel dan Anton ke jalanan tempat pertama kali mereka bertemu, di kolong jalan layang. Di sana mereka diajarkan untuk mencari uang. Anton dan Angel diajarkan bagaimana nanti saat lampu merah menyala, mereka mendekati mobil sambil bernyanyi kecil apa saja dan bertepuk tangan. Angel dan Anton pun mengerti, mereka diajarkan untuk mengemis di jalanan.

Dalam novel Surat Kecil untuk Tuhan halaman : 183- Setiap harinya Om Rudy menuntut maria untuk menyetorkan uang sebesar Rp 100.000. Bila ia tidak mampu mengumpulkan uang sebanyak itu, maka hari itu juga maria tidak diperbolehkan tidur dan makan di rumah.\|

\section{d. Bibi Feli dan Paman Marcus}

Bibi Feli dan Paman Marcus merupakan tokoh tambahan dalam novel Surat Kecil untuk Tuhan karena tokoh bibi Feli dan paman Marcus muncul tiga kali saja yaitu di awal cerita. Bibi Feli dan Paman Marcus merupakan pasangan suami istri di dalam novel Surat Kecil untuk Tuhan. Merekalah yang merawat Anton dan Angel setelah kedua orang tua mereka meninggal akibat kecelakaan bus. Sikap bibi Feli dan paman Marcus berbeda. Sikap bibi Feli yang baik, penyayang, dan menerima Anton dan Angel dengan terbuka lebar berbeda dengan paman Marcus yang keras, kasar dan tidak suka 
serta menerima Anton dan Angel dengan baik untuk tinggal bersamanya. Hal ini terlihat dalam kutipan novel SKUT halaman : 6 -Syukurlah kalian tidak apa-apa.., ujar Bibi Feli dengan wajah penuh kesedihan. -Ayah dan ibu dimana?\| Bibi Feli dan ketua RT saling menatap. -Ayah dan ibu kalian telah meninggal..॥ suara pelan Bibi Feli saat mengucapkan kalimat itu terasa seperti teriakan di telingga Anton. -Bibi bohong ! Ayah dan ibu hanya pergi sebentar dan janji akan pulang.\|

-Bibi tidak bohong. Ayah dan ibu kamu kecelakaan bus saat kembali ke Jakarta.॥

-Bibi bohong...bohong.. II Anton mulai menangis. Pria tua yang juga ketua RT, kini mendekati Anton untuk meyakinkan apa yang terjadi.

-Apa yang dikatakan bibi kamu itu benar. Ayah dan ibu kamu sudah dipanggil yang Maha Kuasa. Bibi kamu datang ke sini untuk merawat kalian.\|

Dalam novel SKUT halaman : 8 -Keduanya kemudian diasuh oleh Bibi Feli, yang memiliki suami pengangguran dan menghabiskan hampir seluruh waktunya di rumah. Sementara Bibi Feli berjualan sayur di pasar setiap hari dan menjadi sumber penghasilan mereka satu-satunya.

Dalam novel SKUT halaman : 15 -Bibi Feli pulang dengan kebingungan ketika melihat rumahnya penuh tangis. Ia sadar suaminya telah melakukan tindakan yang tidak layak pada kedua keponakannya. Ia merasa menyesal, tapi tak bisa berbuat apa-apa selain diam. Di hadapan ketiganya, Paman Marcus mengancam dengan penuh amarah.

-Yang berkuasa di rumah ini adalah saya, rumah ini punya saya. Kalau kalian tidak senang, silakan keluar.॥

Anton dan Angel berpelukan dengan penuh ketakutan dan wajah memar. Mereka masuk ke kamar dan mengunci diri.

Sementara Paman masih melampiaskan amarahnya pada bibi. Angel memegang luka kakaknya, ada darah segar di sudut bibir yang terkena hantaman sapu Paman.

\section{e. Tante Soraya dan Edwards}

Tante soraya dan suaminya Edwards merupakan tokoh tambahan dalam novel Surat Kecil untuk Tuhan karena mereka hanya keluar di pertengahan cerita saja. Tante soraya adalah orang yang membantu Angel saat mengalami kecelakaan di lampu merah, dan bersama suaminya menjadi orang tua angkat Angel. Sosok tante soraya dan Edwards merupakan sosok yang baik hati bagaikan malaikat, tulus, pengertian dan sangat penyayang.

Hal ini terlihat dalam kutipan novel SKUT halaman : 89 -Tante, tolong adik saya...tolong.., $\|$ ratap anton yang kini mulai mencemaskan adiknya. 
-Tenang ya, Nak. Tante akan tolong adik kamu. Kita ke rumah sakit... Orang tua kamu dimana?\|

Sudah tidak ada, kami hanya tinggal berdua.॥

-Ada saudara atau siapa saja yang bisa kamu huungi?॥

-Om Rudy, dia yang mmenampung kami.\|

-Baiklah, nanti kalau sudah sampai di rumah sakit, kamu hubungi Om Rudy. Tante yang akan urus adik kamu. Oke?॥

-Iya tante.॥

Dalam novel SKUT halaman : 91 -Melihat Anton datang bersama Om Rudy, Tante Soraya langsung menyambut mereka. Om Rudy memperkenalkan dirinya sebagai orang tua asuh Anton dan Angel. Tante Soraya memberitahu mereka ia belum mendapat kabar tentang keadaan Angel karena sejak tadi belum ada dokter yang keluar dari UGD untuk memberi keterangan.

Dalam novel SKUT halaman : 105 -Sementara itu di rumah sakit, Soraya datang bersama suaminya, Edwards, seorang diplomat kedutaan Australia ia menanyakan kondisi Angel, yang ternyata mengalami masalah secara administrasi karena tidak ada yang bertanggung jawab. Akhirnya perempuan itu memutuskan mengambil alih dan melunasi semua biaya serta tindakan medis yang diperlukan untuk menyelamatkan Angel.

\section{f. Maria}

Maria merupakan tokoh tambahan dalam novel Surat Kecil untuk Tuhan karena tokoh maria hanya muncul di akhir cerita saja. Maria adalah salah satu korban eksploitasi yang dilakukan oleh om Rudy. Maria merupakan sosok yang sabar, kuat tegar, pemberani, dan baik hati.

Dalam novel SKUT halaman : 159 -Selama berminggu-minggu Angel melakukan rutinitas ini untik mereka hingga di suatu akhir pecan, ia menemukan seorang anak yang tengah sakit tetapi tetap mengamen di jalanan. Nama anak itu Maria, usianya baru 10 tahun.

Dalam novel SKUT halaman : 182 -Sebagai saksi korban, walaupun masih di bawah umur, Maria harus bersaksi di bawah sumpah. Ia berjalan pelan menuju kursi saksi tepat di depan meja Majelis Hakim. Suara gadis cilik itu terdengar bergetar ketika mengucapkan sumpahnya, menandakan rasa gugup. 


\section{g. Wira}

Wira merupakan tokoh tambahan dalam novel Surat Kecil untuk Tuhan karena tokoh wira hanya muncul delapn kali yaitu pertengahan dan di akhir cerita. Wira merupakan teman dari Anton dan Angel dari kecil hingga dewasa yang kemudian menjadi tunangan Angel. Wira merupakan sosok yang sabar, periang, tabah, baik, sopan, pintar dan rendah hati.

Hal ini terlihat dalam novel SKUT halaman : 60 -Sebuah mobil mewah kemudian berhenti di depan lampu merah. Seorang anak terlihat duduk di kursi belakang sementara ayah dan ibunya berada di kursi depan. Anak laki-laki kecil itu usianya mungkin sebaya Anton, tapi ia memakai alat bantu pernafasan yang terpasang di hidungnya. Dalam novel SKUT halaman : 64 -Seperti biasa mereka sekeluarga akan pergi menemui dokter spesialis jantung yang telah merwat Wira setahun lalu, sebelum ia memberi rujukan kepada dokter di Singapura.

Dalam novel SKUT halaman : 67 -Keesokan harinya, seperti sebuah janji yang telah ditepati, mobil Wira yang tak akan pernah mereka lupakan, muncul tepat di lampu merah. Mereka mendekat menyambut Wira, yang tak akan pernah lupa dengan senyum tulus dan hiburan kakak beradik itu. Ketika Wira memberi uang pada Angel, Angel pun memberikan gambar yang telah ia buat sebagai hadia untuk Wira.

Dalam novel SKUT halaman : 81 -Dengan wajah sedih, Wira terpaksa meninggalkan kedua sahabat yang telah memberinya banyak kebahagiaan itu. Kalung yang diberikan Angel kini sudah menggantung di lehernya. Perpisahan ketiga sahabat ini menyimpan misteri yang tak akan pernah mereka ketahui.

Dalam novel SKUT halaman : 109 -Jauh di negeri Cina, di kota Shenzen yang berdekatan dengan kota Hong Kong, orang tua Wira terlihat di sebuah rumah sakit dengan wajah gelisah. Hari itu Wira menjalani operasi pencangkokan jantung, yang telah mereka dapatkan dari pasar gelap.

Dalam novel SKUT halaman : 137 -Angel dan Martin membuat janji untuk bertemu di kampus tempat Angel kuliah. Perpustakaan kampus mereka pilih sebagai tempat pertemua setelah saling bertukar nomor telepon lewat email.

Dalam novel SKUT halaman : 146 -Saat makan malam untuk merayakan kelulusan Angel, Wira tiba-tiba memberikan bunga dan sebuah cincin kepadanya. Dentingan piano yang sengaja dipesan Wira untuk momen ini, mengiringi aksinya berlutut di hadapan Angel sambil berkata, -Angel.. maukah kau menikah denganku dan menerima cincin tunangan ini?\|

Dalam novel SKUT halaman : 210 -Mobil yang membawa Wira dan keluarganya berjalan melewati mobil Angel. Wira yang tengah menatap jauh ke pantai 
lewat jendela mobilnya melihat sosok Angel di sana. Ia meminta supir keluarganya menghentikan mobil dan keluar untuk memastikan penglihatannya.

\section{h. Mirna}

Mirna merupakan tokoh tambahan dalam novel Surat Kecil untuk Tuhan karena mina hanya muncul di pertengahan cerita. Mirna adalah teman dari Anton dan Angel saat tinggal bersama di rumah Om Rudy. Mirna adalah sosok seorang teman yang baik, penyayang, rajin dan polos.

Dalam novel SKUT halaman : 42 -Seorang anak perempuan bernama Mirna, yang sedikit lebih besar dari Angel, mendekat pada gadis itu.

-Kamu tidak menyumbang Om Rudy?\|

-Menyumbang untuk apa?\|

-Ya sumbangan untuk Om Rudy, supaya kita di kasih makan enak dan tidur enak.ll

-Aku belum berpikir untuk itu. Memangnya harus?॥

-Tidak juga sih, tapi kalu ada sumbangan akan bagus.

Nanti uang sumbangan itu akan diberikan lagi pada kita untuk mencari orang tua angkat. Sudah banyak kakak yang menyumbang akhirnya mendapat orang tua asuh. Hidup bahagia... punya ibu dan ayah yang baik.

\subsubsection{Jenis-jenis Tokoh}

Tokoh cerita yang ada di dalam cerita fiksi dapat dibedakan ke dalam beberapa penamaan berdasarkan sudut pandang penamaan itu dilakukan. Berikut ini beberapa pembedaan tokoh dari sudut pandang yang berbeda:

\section{a. Tokoh Utama dan Tokoh Tambahan}

Pembedaan tokoh dalam kategori ini didasarkan pada peran dan pentingnya pemeran tokoh dalam cerita fiksi secara menyeluruh. Dalam segi peranan atau tingkat pentingnya tokoh dalam sebuah cerita tersebut, ada tokoh yang termaksud tokoh pemeran yang penting dan diceritakan berulang-ulang sehingga terlihat seperti mendominasi sebagian besar cerita. Sebaliknya, ada juga tokoh-tokoh yang hanya ditampilkan sekali atau beberapa kali dalam cerita. itu pun mungkin dalam porsi narasi yang relatif pendek. Tokoh yang disebut pertama adalah pemeran utama cerita (central character), sedang tokoh yang kedua adalah pemeran tambahan atau pemeran periferal (peripheral character) (Nurgiyantoro, 1994:258).

Pemeran utama adalah tokoh yang diutamakan dalam penceritaann novel. Pemeran utama merupakan tokoh yang paling banyak diceritakan. Baik sebagai pelaku 
peristiwa dalam cerita maupun sebaliknya. Ada pula pendapat lain yang menyatakan bahwa pemeran utama adalah tokoh yang terbilang penting yang ditampilkan terus menerus sehingga terasa seperti mendominasi sebagian besar cerita (Suyanto, 2012:49).

Pada novel tertentu, pemeran utama senantiasa hadir pada setiap halaman buku cerita yang berkaitan. Pemeran utama sering kali diceritakan dan selalu berhubungan dengan tokoh yang lain. Hal itu yang menentukan perkembangan plot dalam sebuah cerita secara keseluruhan. Pemeran utama selalu hadir sebagai pelaku atau yang berhubungan langsung dengan kejadian dan konflik penting yang mempengaruhi perkembangan plot. Plot utama sebenarnya tidak lain ialah cerita tentang tokoh utama, bahkan kehadiran plot-plot lain atau subplot lazimnya berfungsi untuk memperkuat eksistensi tokoh utama itu juga (Nurgiyantoro, 1994 : 259).

Dalam novel Surat Kecil untuk Tuhan terdapat dua tokoh utama yaitu tokoh Anton dan Angel. Anton dan Angel memiliki peran penting dalam cerita dan sering diceritakan. Berikut ini indikator tokoh utama adalah sebagai berikut.

1. Pelaku kejadian atau dikenai kejadian

2. Frekuensi kehadirannya lebih banyak pada setiap bab

3. Pemeran yang paling banyak diceritakan

Di pihak lain, pemunculan tokoh-tokoh tambahan biasanya tidak terlalu muncul atau paling tidak kurang mendapat perhatian. Pemeran utama adalah yang dibuat sinopsisnya, seperti dalam bagian pembuatan sinopsis, sedangkan tokoh tambahan biasanya tidak terlalu hadir dalam cerita karena sinopsis hanya berisi intisari cerita. Pemeran tambahan adalah tokoh yang dimunculkan hanya beberapa kali dalam porsi penceritaan yang relatif pendek (Suyanto, 2012: 49).

Dalam novel Surat Kecil untuk Tuhan terdapat enam tokoh tambahan yang dimunculkan hanya beberapa kali dalam cerita yaitu Bibi Feli, Paman Marcus, Tante Soraya, Edwards, Maria, Wira dan Mirna. Berikut ini indikator jenis tokoh tambahan yaitu:

1. Kehadirannya han ya sekilas

2. Tokoh yang diabaikan kisahnya

3. Tokoh yang sedikit mendapat perhatian dari pengarang maupun pembaca.

Pemeran utama merupakan sebuah novel yang mungkin saja lebih dari seorang walau kadar keutamaannya belum tentu mirip. Keutamaan dari mereka diperoleh dari dominasi banyaknya penceritaan serta pengaruhnya kepada perkembangan plot secara keseluruhan

(Nurgiyantoro, 1994:

261). 


\section{KESIMPULAN}

Karya sastra adalah bentuk komunikasi yang diucapkan dengan cara yang khas dan memberikan kemampuan kepada pengarang untuk menuangkan kreativitas imajinasinya seperti ungkapan pikiran dan perasaan, berupa kisah maupun kehidupan sehari-hari. Berawal dari inilah kemudian muncul berbagai teori untuk mengkaji karya sastra, termasuk karya sastra novel.

Novel merupakan karya sastra berbentuk prosa yang mengandung serangkaian cerita kehidupan. Sebuah novel biasanya menceritakan kehidupan manusia dalam berinteraksi dengan lingkungan dan sesamanya. Novel yang dimaksudkan di sini adalah novel surat kecil untuk Tuhan karya Agnes Davonar.

Novel Surat Kecil untuk Tuhan karya Agnes Davonar ini memiliki dua tokoh utama yaitu tokoh Anton dan Angel, dan beberapa tokoh pendukung lainnya seperti paman Marcus, bibi Feli, tante Soraya dan suaminya, om Rudy, Maria, Martin Wira dan Mirna.

\section{DAFTAR PUSTAKA}

Davonar, Agnes 2016 Surat Kecil untuk Tuhan. Falcon Publishing, Jakarta.

Minderop, Albertine. 2005. Metode Karakteristik Telaah Fiksi. Yayasan Obor Indonesia, Jakarta.

Nurgiyantoro, Burhan. 2002. Teori Pengkajian Fiksi. Gajah Mada University Press, Yogyakarta.

Sugihastuti dan Suharto. 2002. Kritik Sastra Feminis Teori dan Aplikasinya. Pustaka Pelajar, Yogyakarta.

Suroso, dkk. 2009. Kritik Sastra : Teori, Metodologi, dan Aplikasi. Elmatera Publishing, Yogyakarta.

Suyanto, Edi. 2012. Perilaku Tokoh dalam Cerpen Indonesia. Universitas Lampung, Bandar Lampung.

Tarigan, Henry Guntur. 2011. Prinsip-prinsip Dasar Sastra.. Angkasa Bandung

Zaidan, Abdul Rosak, dkk. 2004. Kamus Istilah Sastra. Balai Pustaka, Jakarta 